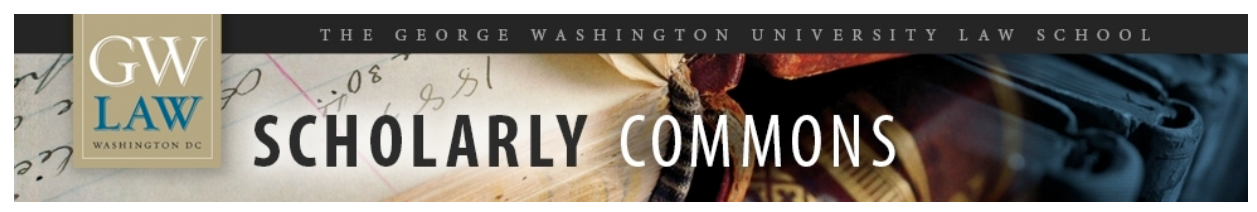

\title{
With Great Power Comes Great Responsibility: Proposed Principles of Digital Due Process for ICT Companies
}

\author{
Dawn C. Nunziato \\ George Washington University Law School, dnunziato@law.gwu.edu
}

Follow this and additional works at: https://scholarship.law.gwu.edu/faculty_publications

Part of the Law Commons

\section{Recommended Citation}

Nunziato, Dawn Carla, With Great Power Comes Great Responsibility: Proposed Principles of Digital Due Process for ICT Companies (December 31, 2013). GWU Law School Public Law Research Paper No. 2017-53; GWU Legal Studies Research Paper No. 2017-53. Available at SSRN: https://ssrn.com/ abstract $=2989993$

This Article is brought to you for free and open access by the Faculty Scholarship at Scholarly Commons. It has been accepted for inclusion in GW Law Faculty Publications \& Other Works by an authorized administrator of Scholarly Commons. For more information, please contact spagel@law.gwu.edu. 


\section{With Great Power Comes Great Responsibility: Proposed Principles of Digital Due Process for ICT Companies}

\section{- Dawn Carla Nunziato}

\section{Introduction}

Information and Communications Technology (ICT) companies like Google/YouTube, Facebook, Yahoo, and Twitter are in control of an enormous amount of expression on the Internet. More so than any individual country, these companies are responsible for making decisions with regard to a vast amount of Internet expression. They host billions of pages of Internet content, while responding on a daily basis to countless requests from countries and individuals around the world to take down content that is deemed objectionable or illegal. These powerful ICT companies have become the de facto sovereigns of cyberspace, with the power to balance freedom of expression against public and private interests on a day-to-day basis, as they make determinations about whether and when to accede to requests to censor speech. In the words of First Amendment scholar Jeffrey Rosen, the "fresh-faced tech executives ... in charge of their companies' content policies... [have] more power over who gets heard around the globe than any politician or bureaucrat — more power, in fact, than any president..." ${ }^{1}$ These decision-makers have insufficient guidance and inadequate guidelines for carrying out these awesome responsibilities that have a dramatic impact on the global contours of freedom of speech.

Google, for example, is responsible for facilitating seventy-one percent of the world's Internet searches. ${ }^{2}$ As the owner of YouTube, Google is also responsible for hosting one hundred hours of new video content that users post every minute. ${ }^{3}$ This is in addition to its ownership of other widely used applications, including the blog site Blogger, the photo-sharing site Picasa, and the social networking site Orkut. Executives at Google are responsible for making determinations about which controversial content stays up and which comes down. Twitter decision-makers enjoy similar, vast power to determine which of the one billion tweets sent every five days get disseminated around the world and which get blocked. ${ }^{4}$ The same goes for Facebook, Yahoo, and other global ICT giants.

What guidelines should these companies follow in determining which content to facilitate and which to take down? Under what circumstances should ICT companies

\footnotetext{
1 Jeffrey Rosen, The Delete Squad: Google, Twitter, Facebook and the New Global Battle Over the Future of Free Speech, April 29, 2013

${ }^{2} \mathrm{http}: / / \mathrm{www}$.netmarketshare. com/search-engine-market-share. aspx $?$ qprid=4\&qpcustomd $=0$

${ }^{3} \mathrm{http}: / / \mathrm{www} . y o u t u b e . c o m / \mathrm{yt} / \mathrm{press} / \mathrm{statistics.html}$

${ }^{4} \mathrm{http}: / / \mathrm{www}$.statisticbrain.com/twitter-statistics/
} 
accede to governments' or individuals' requests to censor content? How, if at all, should they implement such censorship requests? Given that most of these powerful companies are U.S. based, some have contended that these companies should implement the United States' speech-protective values and refuse censorship requests from other, less speechprotective countries. ${ }^{5}$ For example, if France requests that a U.S. based ICT company like Yahoo block content that violates French hate-speech laws, Yahoo arguably should simply ignore the request and export the First Amendment to other countries. But after a French court decision in 2000 rendered Yahoo criminally liable in France for failing to block French citizens' access to certain hate speech content it hosted, Yahoo - and other global ICT companies -- began to rethink this approach. Although initially resisting France's power to influence what content Yahoo hosts - resulting in lengthy legal battles -- Yahoo ultimately modified its policies to prohibit hosting of hate speech content. Instead of Yahoo exporting the First Amendment, it would seem in this instance that France exported its own less speech-protective laws to the U.S. and the rest of the world. How should global ICT companies respond to countries' requests to censor content in light of the Yahoo-France dispute, in which France asserted the power to seize Yahoo's local assets and detain local Yahoo executives for failing to comply with its laws? Is there a middle ground between imposing the First Amendment on the rest of the world, and acceding to every other country's speech-restrictive censorship requests? How should global ICT companies balance these myriad competing concerns, amidst vastly conflicting regional free speech regimes?

In this chapter, I argue that ICT companies should adopt and implement a set of procedural guidelines embodying principles of digital due process that protect the due process rights that are essential to democratic societies, while respecting the autonomy of each democratic society to determine the contours of substantive free speech rights for its citizens. Protecting due process rights is the first step in protecting and respecting human rights, which transnational corporations - as well as countries - have a duty to protect. As United Nations' Special Representative of the Secretary-General emphasized in his "Protect, Respect and Remedy" framework, business enterprises as well as nations have a duty to respect human rights. ${ }^{6}$ An important part of respecting human rights is respecting the rights of individuals to receiving due process in the protection of their rights. ICT companies should adopt and implement a set of due process principles that, I argue, are implicit in the free speech and due process jurisprudence of the International Covenant on Civil and Political Rights, the European Convention on Human Rights, and the United States Constitution. Before implementing any country's request that they block content, ICT companies should (1) ensure that the requesting country has articulated within its laws a narrow, specific description of what speech is illegal, to

\footnotetext{
${ }^{5}$ See, e.g., Rosen, supra note 1.

${ }^{6}$ See Report of the Special Representative of the Secretary-General on the issue of human rights and transnational corporations and other business enterprises, John Ruggie, Guiding Principles on Business and Human Rights: Implementing the United Nations "Protect, Respect and Remedy" Framework. A/HRC/17/31.
} 
confine the discretion of decision-makers and to provide fair notice to individuals of what speech is illegal in the first instance; (2) ensure that affected parties have received notice in cases where their speech has been deemed illegal and have had the opportunity to be heard in a fair, independent, and impartial proceeding before a censorship decision is ordered; (3) require that the requesting country has issued a narrowly tailored, final judicial decision adjudicating the subject speech as illegal; (4) implement the resulting blocking order only within the country mandating such blocking; and (5) implement the resulting blocking order in an open and transparent manner. Below I explore the sources of these principles of digital due process for Internet free in the International Covenant, the European Convention, and the U.S. Constitution.

\section{Substantive and Procedural Protections for the Right to Freedom of Expression}

While international, European, and U.S. instruments provide for substantive protections for the right to freedom of expression, the language of these instruments allows for substantial discretion to be exercised by different countries in construing these provisions. Although there is a resultant wide variation among countries regarding substantive protections for speech - including which categories of speech are protected and which are unprotected - there is a growing convergence regarding procedural protections for speech. Below I first briefly explore the substantive dimensions before turning to the procedural dimensions of protection for freedom of expression.

The International Covenant on Civil and Political Rights (ICCPR), ${ }^{7}$ which has been adopted by 167 parties and is considered a binding international law treaty, provides in Article 19 that:

1. Everyone shall have the right to hold opinions without interference.

2. Everyone shall have the right to freedom of expression; this right shall include freedom to seek, receive and impart information and ideas of all kinds, regardless of frontiers, either orally, in writing or in print, in the form of art, or through any other media of his choice. ${ }^{8}$

3. [These rights] may . . . be subject to certain restrictions, but these shall only be such as are provided by law and are necessary:

(a) For respect of the rights or reputations of others;

(b) For the protection of national security or of public order (ordre public), or of public health or morals. ${ }^{9}$

The right to freedom of expression is also protected under the European Convention on Human Rights, which has been signed by 47 nations. Article 10 of the European Convention provides:

\footnotetext{
${ }^{7}$ International Covenant on Civil and Political Rights, G.A. Res. 2200, U.N. GAOR, $21{ }^{\text {st }}$ Sess., Supp. No. 16, at 52, U.N.Doc A/6316 (1966) (hereinafter ICCPR).

${ }^{8}$ ICCPR, supra note 31, Art. 19.

${ }^{9}$ ICCPR, supra note 31, Art. 19. The ICCPR provides further, in Article 20, that any propaganda for war or advocacy of national, racial, or religious hatred that constitutes incitement to discrimination, hostility, or violence, is prohibited by law. Id., Art. 20.
} 
Everyone has the right to freedom of expression. This right shall include freedom to hold opinions and to receive and impart information and ideas without interference by public authority and regardless of frontiers....

The exercise of these freedoms . . . may be subject to such formalities, conditions, restrictions or penalties as are prescribed by law and are necessary in a democratic society, in the interests of national security, territorial integrity or public safety, for the prevention of disorder or crime, for the protection of health or morals, for the protection of the reputation or rights of others, for preventing the disclosure of information received in confidence, or for maintaining the authority and impartiality of the judiciary. ${ }^{10}$

Finally, the First Amendment to the United States Constitution provides that "Congress shall make no law . . . . abridging the freedom of speech, or of the press ...." The jurisprudence developed in interpreting and applying these protections for free speech not only has a substantive dimension of which categories of speech to protect and which to restrict-which differ from country to country ${ }^{11}$ - but also has important procedural dimensions, which require that "sensitive tools" be implemented to distinguish between protected and unprotected speech. ${ }^{12}$ As free speech theorist Henry Monaghan explains, "procedural guarantees play an equally large role in protecting freedom of speech; indeed, they assume an importance fully as great as the validity of the substantive rule of law to be applied.... Whenever [freedom of expression] claims are involved, sensitive procedural devices are necessary." 13

While there is great variation among countries regarding substantive protections for speech - including which types of speech are illegal -- there is more widespread agreement regarding the procedures that are essential to ensure meaningful protections for speech. These procedural protections were recently expounded upon by the U.N. Special Rapporteur on the Promotion and Protection of the Right to Freedom of Opinion and Expression in his May 2011 Report to the Human Rights Council. While recognizing that countries enjoy some discretion to restrict child pornography, hate speech,

10 See European Convention for the Protection of Human Rights and Fundamental Freedoms (ETS 5), 213 U.N.T.S. 222 entered into force Sept. 3, 1953, as amended by Protocol 11 (ETS 155) which entered into force May 11, 1994 (hereinafter European Convention).

${ }^{11}$ See, e.g., Ronald J. Krotoszynski, Jr., The First Amendment in Cross-Cultural Perspective: A Comparative Legal Analysis of the Freedom of Speech (2006); Robert A. Sedler, Freedom of Speech: The United States versus The Rest of the World, 2006 Mich. St. L. Rev. 377; Stephanie Farrior, Molding the Matrix: The Historical and Theoretical Foundations of International Law Concerning Hate Speech, 14 Berk. J. Int'1 L 1 (1996).

${ }^{12}$ Bantam Books v. Sullivan, 372 U.S. 58 (1963).

${ }^{13}$ Malinski v. New York, 324 U.S. 401, 414 (1945) (Frankfurter, J., concurring). 
defamation, incitement to genocide, discrimination, hostility, or violence, the Special Rapporteur explained that:

Any limitation to the right to freedom of expression must pass the following [multi]-part, cumulative test:

It must be provided by law, which is clear and accessible to everyone (principles of predictability and transparency);

It must pursue one of the purposes set out in article 19, paragraph 3, of the [International Covenant on Civil and Political Rights], namely (i) to protect the rights or reputations of others, or (ii) to protect national security or of public order, or of public health or morals (principle of legitimacy);

It must be proven as necessary and the least restrictive means required to achieve the purported aim (principles of necessity and proportionality)[;]

[It] must be applied by a body which is independent of any political, commercial, or other unwarranted influences in a manner that is neither arbitrary nor discriminatory, and with adequate safeguards against abuse, including the possibility of challenge and remedy against its abusive application. $^{14}$

Similarly, European and U.S. free speech jurisprudence embodies procedural requirements for any abridgements of the right to freedom of expression. Within the context of United States First Amendment jurisprudence, courts have constructed a powerful "body of procedural law that defines the manner in which they and other bodies must evaluate and resolve First Amendment claims - a First Amendment 'due process." "15 In so doing, courts have developed "a comprehensive system of procedural safeguards designed to obviate the dangers of a censorship system.",16

\section{Digital Due Process Principle 1: Before implementing any country's request that they block content, ICT companies should ensure that the requesting country has articulated within its laws a narrow, specific description of what speech is illegal, to confine the discretion of decision- makers and to provide fair notice to individuals of what speech is illegal in the first instance.}

\footnotetext{
${ }^{14}$ Frank La Rue, Report of the Special Rapporteur on the Promotion and Protection of the Right to Freedom of Opinion and Expression, United Nations Human Rights Council, at http://www2.ohchr.org/english/bodies/hrcouncil/docs/17session/A.HRC.17.27_en.pdf

${ }^{15}$ See Henry Monaghan, "First Amendment Due Process," 83 Harv. L. Rev. 518 (1970).

${ }^{16}$ See Monaghan, supra note 43.
} 
In democratic societies, individuals have a right to conduct their lives so as to conform their conduct to the dictates of the law in order to avoid violations of the law. As the United States Supreme Court has explained, "Living under a rule of law entails various suppositions, one of which is that [all persons] are entitled to be informed as to what the State commands or forbids." 17 This in turn requires laws that clearly and precisely indicate what conduct is illegal, so that individuals can steer clear of such conduct. Because of the paramount importance of freedom of expression to democratic societies, it is especially important that laws regulating speech do so in a narrow and precise manner, to avoid creating a chilling effect on expression. Although democratic countries, as sovereign nations, enjoy the power to determine what categories of speech are illegal (subject to the dictates of the International Covenant and European Convention), they should formulate laws articulating which categories of speech are illegal in as narrow and precise a manner as language permits. Therefore, before implementing a blocking order from a country, ICT companies should require that the requesting country has articulated within its laws a narrow, specific description of what speech is illegal, to confine the discretion of decision-makers and to provide fair notice to individuals of what speech is illegal in the first instance. The International Covenant, the European Convention, and the U.S. First Amendment each provides support for the first proposed principle of digital due process, as I explain below.

The International Covenant requires that any limit on the right to freedom of expression be provided by a law that is transparent, clear, and accessible to everyone, such that it is predictable that one's speech will be subject to regulation. In addition, in its Article 10 jurisprudence, the European Court of Human Rights has also made clear that Article 10 requires that laws restricting speech must be "clear and precise" and must indicate with sufficiently clarity the scope of any legal discretion enjoyed by the decision-maker and the manner of its exercise. Notably, in a 2012 case involving the wholesale blocking of the entire Google Sites platform within Turkey - discussed in greater detail below -- the European Court of Human Rights had occasion to reiterate the requirements for laws restriction freedom of expression. The Court explained that individuals whose conduct is affected by laws restricting freedom of expression must be able to foresee the law's consequences, and therefore the law restricting expression must be formulated with sufficient precision to enable any individual to regulate his conduct under the law. This requirement affords individuals legal protection against arbitrary interferences by public authorities with rights guaranteed by the Convention. ${ }^{18}$

In addition, under U.S. First Amendment jurisprudence, laws restricting expression must be articulated in a manner that is clear, precise, and specific. The U.S. Supreme Court has repeatedly held that laws restricting speech that are vague or overbroad are invalid. The Supreme Court has also rejected as unconstitutional any system of censorship that reposits unbounded discretion in

\footnotetext{
${ }^{17}$ Papachristou v. Jacksonville, 405 U. S. 156, 162 (1972).

${ }^{18}$ See Yildirim v. Turkey, Pars. 57-59.
} 
the decision-maker to determine whether or not speech is protected.

First, without reference to the substantive categories of which speech can constitutionally be deemed illegal, the U.S. Supreme Court has rejected laws that are framed in vague and imprecise terms -- both on First Amendment and on Due Process grounds -- because such laws fail to provide clear notice of what speech is prohibited and allow for government officials to exercise standardless discretion. The legislature is required to formulate laws regulating speech "with sufficient definiteness [so that] ordinary people can understand what is prohibited"19 and "in a manner that does not encourage arbitrary and discriminatory enforcement."20 The "requirement of clarity in regulation is essential to the protections provided by the Due Process Clause." ${ }^{21}$ A law will therefore be struck down as unconstitutionally vague if persons "of common intelligence must necessarily guess at its meaning and differ as to its application.",22

Laws that do not clearly and precisely define the proscribed content are constitutionally infirm because they are fundamentally unfair. Such laws "trap the innocent by not providing fair warning" of what expression is prohibited and because they impermissibly delegate "basic policy matters to policemen, judges and juries for resolution on an ad hoc and subjective basis, with the attendant dangers of arbitrary and discriminatory application." 23 In particular, the U.S. Supreme Court has explained that vague laws have a chilling effect on expression, as such laws tend to lead citizens to "steer far wider of the unlawful zone than if the boundaries of the forbidden [were] clearly marked." 24 On these grounds, the Supreme Court has, for example, rejected a law that, in part, prohibited "treat[ing] contemptuously the flag of the United States," because it failed "to draw reasonably clear lines between the kinds of . . . treatment that are criminal and those that are not." ${ }^{, 25}$ Although laws regulating non-expressive conduct may also be struck down on vagueness grounds, vague laws regulating expression are particularly carefully scrutinized because of the danger of chilling constitutionally protected speech. As the Court has explained, "[b]ecause First Amendment freedoms need breathing space to survive, the government may regulate in the area only with narrow specificity." 26

The U.S. Supreme Court has also consistently rejected laws that are overbroad -- laws that sweep too broadly so as to encompass both unprotected speech and protected speech. For example, a law that criminally prohibited the use of "opprobrious words or abusive language, tending to cause a breach of the

\footnotetext{
${ }^{19}$ Kolender v. Lawson, 461 U.S. 352, 357 (1983).

${ }^{20} \mathrm{Id}$.

${ }^{21}$ United States v. Williams, 553 U. S. 285, 304 (2008).

${ }^{22}$ Connally v. General Construction Co., 269 U.S. 385, 391 (1926).

${ }^{23}$ Grayned v. Rockford, 408 U.S. 104, 108-9 (1972).

${ }^{24}$ Grayned, 408 U.S. at 109 and n.5.

${ }^{25}$ Smith v. Goguen, 415 U.S. 566, 572-73 (1974).

${ }^{26}$ NAACP v. Button, 371 U.S. 415, 432-33 (1963).
} 
peace" was held to be unconstitutionally overbroad, even though it could constitutionally be applied to prohibit certain types of particularly harmful expression, because it could also be unconstitutionally applied to protected expression. $^{27}$ In addition, the Supreme Court has invalidated systems for licensing speech that vest unbridled discretion in the initial decision-maker. ${ }^{28}$ In Shuttlesworth v. Birmingham, ${ }^{29}$ for example, the Court evaluated the constitutionality of a parade permitting system that vested the City Commission with the broad discretion to deny parade permits if "in [the Commission's] judgment the public welfare, peace, safety, health, decency, good order, morals or convenience require that [the parade permit] be refused." 30 Because the permitting scheme conferred "virtually unbridled and absolute power" on the Commission, it failed to comport with the essential requirement that any law subjecting the exercise of First Amendment freedoms to a license must embody "narrow, objective, and definite standards. ${ }^{, 31}$

In summary, the International Covenant, the European Convention, and the United States First Amendment each provides strong support for the proposed principle of digital due process that countries be required to articulate narrow, specific descriptions of what speech is illegal, so as to confine the discretion of the decision-maker and so as to provide fair notice to individuals of what speech is illegal. ICT companies should require that this first principle is complied with before acceding to any country's or individual's request to censor speech.

\section{Digital Due Process Principle 2: Before implementing any country's request that they block content, ICT companies should ensure that affected parties have received notice in cases where their speech has been deemed illegal and have had the opportunity to be heard in a fair, independent, and impartial proceeding before a censorship decision is ordered.}

A fundamental component of living under the rule of law is that an individual be accorded with due process of law before his or her rights or liberties are abridged. Due process of law generally requires that an individual be granted the opportunity to state her case before an impartial decision-maker before her rights or liberties are deprived including her fundamental right to freedom of expression. Accordingly, before an ICT company accedes to a country's request to block content, the ICT company should ensure that the individual has received notice and has had the opportunity to be heard by a fair,

\footnotetext{
${ }^{27}$ See Gooding v. Wilson, 405 U.S. 518 (1972); Broadrick v. Oklahoma, 413 U.S. 601 (1973) (to be unconstitutional, overbreadth of statute must not only be real, but substantial as well, in relation to the statute's plainly legitimate sweep).

${ }^{28}$ Such standard-less discretion is an independent ground for finding the law unconstitutional, separate and apart from the absence or presence of a provision for judicial review of the initial decision-making determination, as discussed in greater detail infra.

${ }^{29} 394$ U.S. 147 (1969).

${ }^{30} \mathrm{Id}$. at $149-50$.

${ }^{31} \mathrm{Id}$. at $150-51$.
} 
independent, and impartial proceeding within that country. The International Covenant, the European Convention, and the U.S. Constitution each provide support for this second proposed principle of digital due process, both in specific provisions protecting freedom of expression and in provisions protecting due process of law and fair trials. Below, I first describe the support these instruments provide for the second proposed principle from their freedom of expression provisions. I then describe the support these instruments provide from their due process and fair trial provisions.

\section{II.A. Support from Freedom of Expression Provisions}

In construing the free speech protections in the International Covenant, the U.N. Special Rapporteur on the Promotion and Protection of the Right to Freedom of Opinion and Expression has explained that:

Any legislation restricting the right of freedom of expression must be applied . . . with adequate safeguards against abuse, including the possibility of challenge [before an independent body] and remedy against its abusive application. ${ }^{32}$

The Special Rapporteur has emphasized, in particular, that in order to avoid infringing the freedom of expression rights of Internet users, ICT companies should

only implement restrictions to [the right to freedom of expression] after judicial intervention ...Any determination on what content should be blocked must be undertaken by a competent judicial authority or a body which is independent of any political, commercial, or other unwarranted influences. ${ }^{33}$

Similarly, the European Court of Human Rights in its recent decision in Yildirim $\mathrm{v}$. Turkey has emphasized that any legislation mandating a restriction of freedom of expression in the form of Internet blocking or filtering must embody, at a minimum, a procedure providing for the appeal of such decision to a judicial decision-maker. ${ }^{34}$

Under the U.S. Constitution, it has long has been understood that any government-mandated censorship of speech must be accompanied by judicial review of such a decision in order to be constitutional. Any state-mandated censorship of speech prior to judicial review of the censorship decision constitutes a "prior restraint" that is presumptively unconstitutional. Censorship ordered by the executive branch absence prompt judicial review of such a decision is presumptively invalid. The availability of judicial review of any censorship decision is an essential requirement imposed on any

\footnotetext{
${ }^{32}$ Frank La Rue, Report of the Special Rapporteur on the Promotion and Protection of the Right to Freedom of Opinion and Expression, United Nations Human Rights Council, A/HRC/17/27.

${ }^{33}$ Frank La Rue, Report of the Special Rapporteur on the Promotion and Protection of the Right to Freedom of Opinion and Expression, United Nations Human Rights Council, A/HRC/17/27

Par. 47, 70.

${ }^{34}$ Yildirim v. Turkey, (Application no. 3111/10) at 27-28 (2012) (citations omitted).
} 
state attempt to censor speech. Judicial review of government orders restricting speech and the concomitant notice to affected parties coupled with an opportunity to be heard in a judicial proceeding -- is a fundamental procedural requirement within First Amendment jurisprudence. U.S. courts have consistently emphasized the importance of the availability of prompt judicial review that affords the affected parties notice and an opportunity to be heard before the judicial decision-making regarding censorship determinations. ${ }^{35}$ As the Supreme Court has explained, "because only a judicial determination in an adversary proceeding ensures the necessary sensitivity to freedom of expression, only a procedure requiring a judicial determination suffices to impose a valid final [prior] restraint." 36

In a number of cases involving government attempts to censor speech, the U.S. Supreme Court has emphasized that a judicial determination is a necessary procedural safeguard in the context of the government abridgement of individuals' freedom of expression. The example of Bantam Books v. Sullivan ${ }^{37}$ is illustrative. This case involved a censorship system for determining which books were legal and which were illegal - in the absence of a provision for judicial review of such determinations. In that case, the Rhode Island Commission to Encourage Morality in Youth was charged with investigating and recommending prosecution of booksellers for the distribution of printed works that were obscene or indecent. The Commission reviewed books and magazines in circulation, and notified distributors in cases in which a book or magazine had been distributed that the Commission found objectionable and for which removal from distribution was ordered. In reviewing the constitutionality of this scheme, the Supreme Court first explained that "the separation of legitimate from illegitimate speech calls for . ... sensitive tools" and reiterated its insistence that such censorship schemes must "scrupulously embody the most rigorous procedural safeguards." 38 The Court condemned the fact that, under the scheme at issue, "the publisher or distributor is not even entitled to notice and hearing before his publications are listed by the Commission as objectionable [and ordered for removal]," as well as the fact that there was "no provision whatever for judicial superintendence before notices issue or even for judicial review of the Commission's determinations of objectionableness." 39 The Court concluded that, in the absence of these essential procedural safeguards, the "procedures of the Commission are radically deficient" and unconstitutional. ${ }^{40}$

In sum, the Supreme Court has consistently emphasized the importance of providing affected individuals with notice and an opportunity to be heard in an adversarial judicial proceeding before an individual's right to free speech is abridged. Absent such procedural safeguards, government orders to censor speech are

\footnotetext{
${ }^{35}$ See Thirty-Seven Photographs, 402 U.S. at 372-74; Kingsley Books, Inc. v. Brown, 354 U.S. 436 (1957); Interstate Circuit, Inc. v. City of Dallas, 390 U.S. 676 (1968); Bantam Books, Inc.v. Sullivan, 372 U.S. 58 (1963).

${ }^{36}$ See United States v. Pryba, 502 F.2d 391, 405 (D.C. Cir. 1974).

${ }^{37} 372$ U.S. 58 (1963).

${ }^{38} I d$. at 66.

${ }^{39} I d$.

${ }^{40} I d$.
} 
unconstitutional. Under the First Amendment - as well as under the free speech protections accorded under the International Covenant and the European Convention notice, opportunity to be heard, and a fair determination of one's free speech rights by an independent decision-maker are required.

\section{II.B. Support from Due Process and Fair Trial Provisions}

The European Convention, the International Covenant, and the United States Constitution also contain provisions for due process of the law and fair trials rights that provide individuals fundamental protections before the state can abridge their right to freedom of expression and opinion. Because state-mandated censorship orders result in a deprivation of individuals' right to freedom of expression, fundamental principles of due process and fair trial rights as articulated in the European Convention, the International Covenant, and the U.S. Constitution require that any such deprivation occur only as a result of a fair, independent, and impartial decision-making process in which affected parties are provided with meaningful notice and an opportunity to be heard. These provisions provide further support for the second proposed principle of digital due process -- the right of the affected parties to receive notice that their speech has been deemed illegal and to have the opportunity to be heard in a fair, independent, and impartial proceeding before a censorship decision is ordered.

The right to a due process of law in general, and to a proper judicial determination of one's rights in particular, is of ancient origin and has its roots in early English and American law. The right to trial by due process of law can be traced to the Magna Carta, which provides that "No freeman shall be ... disseised ... of his liberties...except ... by the law of the land." protections for individual rights is provided in Fifth Amendment to the U.S. Constitution, which provides that "no person shall ... be deprived of . . . liberty ... without due process of law." Similar language was included in the Fourteenth Amendment to the U.S. Constitution, providing that "No State shall . . . deprive any person of . . liberty ..., without due process of law." Since the late 1800s, procedural due process has been linked to the concept of the rule of law. ${ }^{42}$ In the mid-twentieth century, the drafters of the Universal Declaration of Human Rights recognized the importance of protecting due process rights, providing in Article 10 that "Everyone is entitled in full equality to a fair and public hearing by an independent and impartial tribunal, in the determination of his rights and obligations ...." The European Convention on Human Rights was the first international human rights instrument to set forth detailed protections for due process and fair trial rights. ${ }^{43}$ With respect to the determination of civil rights and obligations, the Article 6 of the European Convention provides for the general right to procedural fairness, including a public hearing before a fair, independent, and impartial tribunal that provides a reasoned judgment. Specifically, Article 6(1) states that "In the determination of his civil rights and obligations ..., everyone is entitled to a fair and public hearing

\footnotetext{
${ }^{41}$ Richard Clayton QC and Hugh Tomlinson QC, The Law of Human Rights, at 708 (quoting clause 39 of the Magna Carta of 1215).

${ }^{42}$ Clayton and Tomlinson, 709.

${ }^{43}$ Clayton and Tomlinson, 706
} 
within a reasonable time by an independent and impartial tribunal established by law." Article 14 of the International Covenant similarly provides that "In the determination ... . his rights and obligations ...., everyone shall be entitled to a fair and public hearing by a competent, independent and impartial tribunal established by law." In each of these foundational documents and instruments, procedural due process rights and the right to independent, impartial, and fair judicial determinations of one's civil and human rights are recognized as necessary for the meaningful protection of substantive rights, including the right to freedom of expression. In the words of human rights theorists Richard Clayton and Hugh Tomlinson, "[ $\mathrm{t}]$ he protection of human rights therefore begins but does not end with fair trial rights." 44

Article 6 of the European Convention guarantees procedural fairness "whenever there is a 'determination' of a 'civil right or obligation." "45 The European Court of Human Rights has repeatedly emphasized the centrality of the rights of procedural due process articulated in Article 6(1) and has affirmed that an expansive view of these rights is fundamental to protecting civil and human rights in democratic societies:

In a democratic society within the meaning of the Convention the right to a fair administration of justice holds such a prominent place that a restrictive interpretation of Article 6(1) would not correspond to the aim and purpose of that provision. ${ }^{46}$

Similarly, the Due Process Clause of the United States Constitution requires that before an individual's liberty is deprived by the state, she must be afforded certain fundamental procedural protections. The courts have repeatedly held that the protections provided in the Due Process Clause apply specifically in the content of the deprivation of one's First Amendment right to freedom of expression. As constitutional commentators Rotunda and Nowak explain,

In their procedural aspects, the due process clauses require that the government not restrict a specific individual's freedom to exercise a fundamental constitutional right without a process to determine the basis for the restriction. . . [In particular,] whenever the government seeks to restrain speech, there must be a prompt procedure to determine whether the speech may be limited in conformity with First Amendment principles.

Under the Due Process Clause, before the state deprives an individual of a substantial liberty interest such as the right to freedom of expression, the individual must be accorded at a minimum: adequate notice of the charges or basis for government action; an opportunity to be heard by the decision-maker; a determination by a neutral decisionmaker; and a decision based on the record with a statement of reasons for the decision. ${ }^{47}$

\footnotetext{
${ }^{44}$ Clayton and Tomlinson, 705.

${ }^{45}$ Clayton and Tomlinson, 712.

${ }^{46}$ Delcourt v. Belgium (1970), 1 EHRR 355, para. 25, cited in Clayton and Tomlinson, 824.

${ }^{47}$ See Treatise on Constitutional Law-Substance \& Procedure

Database updated June 2013, Ronald D. Rotunda, John E. Nowak, Chapter 17. Procedural Due Process - The Requirement of Fair Adjudicative Procedures/ II. Deprivations of "Life, Liberty, or
} 
First, regarding the requirement of notice, when the state is considering impairing an individual's constitutionally cognizable liberty interest - such as her right to freedom of expression -- notice must be provided: "An elementary and fundamental requirement of due process in any proceeding ... is notice reasonably calculated, under all the circumstances, to appraise interested parties of the pendency of the action and afford them an opportunity to present their objections." Regarding the nature of the determination, "[w]hile different situations may entail different types of procedures, there is always the general requirement that the government process be fair and impartial. . . . [since] "a fair trial in a fair tribunal is a basic requirement of due process."

In summary, the freedom of expression provisions, as well as the due process and fair trial provision, of international, European, and U.S. instruments provide support for the second proposed principle of digital due process - that before ICT companies implement a country's request that they block content, ICT companies should require that affected parties have received notice that their speech has been deemed illegal and have had the opportunity to be heard in a fair, independent, and impartial proceeding before the censorship decision was ordered.

\section{Digital Due Process Principle 3: Before implementing any country's request that they block content, ICT companies should require that the requesting country has issued a narrowly tailored, final judicial decision adjudicating the subject speech as illegal}

Before complying with any government's request to censor content, ICT companies should require a court order that is narrowly tailored to achieve the compelling government interest at stake in regulating the speech at issue. Because of the paramount importance of freedom of expression in democratic societies, limitations on this freedom, when imposed, should be imposed as narrowly as possible. Before implementing any country's blocking order, ICT companies should ensure that the order is narrowly tailored. The International Covenant, the European Convention, and the U.S. First Amendment each provides support for this proposed principle of digital due process.

First, as discussed above, the International Covenant's freedom of expression provisions require that laws or orders restricting freedom of expression be narrowly tailored. The U.N. Special Rapporteur on the Promotion and Protection of the Right to Freedom of Opinion and Expression explains that:

Any limitation to the right to freedom of expression must . . . be proven as necessary and the least restrictive means required to achieve the purported

Property" for Which Some Process Is Due $§$ 17.4. Liberty, 17.4(c) Fundamental Constitutional Rights 
aim (principles of necessity and proportionality).

In addition, in its First Amendment jurisprudence, the U.S. Supreme Court has repeatedly emphasized that any judicial order regulating speech must be narrowly tailored. Such orders "must be couched in the narrowest terms that will accomplish the pinpointed objective permitted by the [Constitution]" than is necessary" ${ }^{\prime 9}$ to accomplish its objective.

Consistent with the importance of freedom of expression to democratic societies, any judicial order restraining expression must be framed in as narrow a manner as possible to require the surgical blocking of the offending content. Therefore, before implementing any country's request that they block content, ICT companies should require that the requesting country has issued a narrowly tailored judicial decision adjudicating the subject speech as illegal.

\section{Digital Due Process Principle 4: ICT companies should implement a country's blocking order only within the country mandating such blocking}

A foundational principle of national sovereignty is that each nation possesses full control over the affairs within its territorial, geographic boundaries. Under general international law principles, jurisdiction is a nation's assertion of power over the people, properties, and activities within its borders. According to this foundational principle,

The first and foremost restriction imposed by international law upon a State is that - failing the existence of a permissive rule to the contrary - it may not exercise its power in any form in the territory of another State. [Jurisdiction] cannot be exercised by a State outside its territory except by virtue of a permissive rule derived from international custom or from a convention. ${ }^{50}$

While nations enjoy the power to determine the substantive laws within their own territories, they do not enjoy the right to dictate laws that apply outside of their territories. Thus, any order issued by a court mandating that certain content be blocked should be given effect only within the boundaries of that country.

\footnotetext{
${ }^{48}$ Carroll v. President and Comm'rs of Princess Anne, 393 U.S. 175, 183 (1968).

${ }^{49}$ Madsen v. Women's Health Center, 512 U.S. 753, 765 (1994).

${ }^{50}$ The Case of the S.S. "Lotus",PCIJ, Ser.A.,No. 10 (1927), \$19.
} 
In recent years, as discussed in greater detail below, certain countries have sought to bring about the worldwide censorship of speech that offended their national laws but that was protected in other countries. Turkey, for example, urged Google to block access throughout the world to content that allegedly insulted the memory of its founder Mustafa Kemal Ataturk - a criminal offense in Turkey. Although Google blocked access to such content for Internet users in Turkey, Turkish officials apparently claimed that this country-specific blocking was insufficient to protect the rights of Turks living abroad. Google properly refused to accede to this additional, overreaching request to export Turkey's laws to the rest of the world. Because countries generally enjoy the sovereign power to dictate the free speech rights of their people only within their borders, Google was right to refuse Turkey's request in this instance. Consistent with the limited sovereignty of each nation, ICT companies should implement a country's valid blocking order only within the country mandating such blocking.

\section{Digital Due Process Principle 5: ICT companies should implement a country's blocking order in an open and transparent manner.}

An important part of living in a democratic society governed by the rule of law is that individuals are able to know what the law is and how that law is applied to them. In order to engage in the task of democratic self-government, individuals need to be aware of what the law is and how it is applied, so that they can effectively hold the government accountable for its actions. Governments must adopt, implement, and enforce laws in a public, open, and transparent manner, so that individuals have the meaningful ability to check the power of the government and to hold the government accountable for their decision-making. Laws that are adopted, implemented, or enforced in a secretive or opaque manner violate these principles and thwart the goals of democratic selfgovernment. As de facto sovereigns acting to implement the blocking mandates of countries around the world, ICT companies should implement the blocking mandates in a manner that is open and transparent, so that affected individuals are made aware that the content at issue is being blocked by the ICT company at the request of their country. Implementing blocking mandates in an open and transparent manner will enable affected individuals to hold their governments accountable and thereby to exercise the rights that are fundamental to individuals living in democratic societies.

The International Covenant, the European Convention, and the First Amendment support the public, open, and transparent implementation of the law and provide support for the fifth proposed principle of digital due process.

The First Amendment provides individuals with the right to access information concerning government decision-making and in particular, with access to judicial records and judicial proceedings. ${ }^{51}$ Court decisions and court orders are generally publicly

\footnotetext{
${ }^{51}$ In re Globe Newspaper Co., 729 F.2d 47, 52 (1st Cir. 1984) (establishing a First Amendment right of access to records submitted in connection with criminal proceedings); Oregon Publishing
} 
available, so that individuals can hold the government properly accountable for its judicial decision-making. Granting individuals access to information regarding judicial proceedings is essential for individuals to serve as effective check on government. ${ }^{52}$ If the government were to implement judicial decisions in an opaque or secretive manner, this essential component of democratic self-government would be thwarted.

The International Covenant's freedom of expression provisions also provide support for this proposed principle of digital due process. In construing the International Covenant's protections for freedom of expression, the Special Rapporteur has emphasized that in order to avoid infringing the freedom of expression rights of Internet users, Internet intermediaries in implementing any blocking or filtering requests should "be transparent to the user involved about the measures taken, and where applicable to the wider public.. ${ }^{53}$ Such transparency is necessary to achieve the goals of democratic self-government to enable individuals to hold in check the power of their government.

As the entities responsible for implementing the blocking orders of governments around the world, ICT companies should implement these orders in a manner that is open and transparent, so that affected individuals can hold their governments properly accountable for their actions.

\section{ICT Companies' Current Policies Regarding Responses to Countries' Blocking Orders}

Global ICT companies exercise great discretion in determining whether to accede to content removal orders issued from countries or individuals around the world. Although companies like Google have provided a wealth of information regarding the requests they receive and their actions in response to these requests, they tend to provide far less information about the guidelines they follow in determining whether to comply with such requests. While Google is to be commended for publishing its semiannual Transparency Reports with detailed information about requests it has received from governments to remove content and Google's actions in response to such requests, ${ }^{54}$ the only information to be gleaned from its transparency reports is that Google may choose to remove content at the request of a government body when such content violates local

Co.v. United States Dist. Court, 920 F.2d 1462 (9th Cir. 1990)(extending qualified right of access to plea agreements and related documents in criminal cases).

${ }^{52}$ See Globe Newspaper Co.v. Pokaski, 868 F. 2d 497, 502 (1st Cir. 1989); In re Globe Newspaper Co., 729 F.2d 47, 52 (1 st Cir. 1984); United States v. Antar, 38

F.3d 1348, 1359-60 (3d Cir. 1994).

${ }^{53}$ Frank La Rue, Report of the Special Rapporteur on the Promotion and Protection of the Right to Freedom of Opinion and Expression, United Nations Human Rights Council, A/HRC/17/27

Par. 47, 70 .

${ }^{54} \mathrm{http} / /$ www.google.com/transparencyreport/removals/government/ 
law, but it may also choose not to remove such content. ${ }^{55}$ YouTube reports that it will accede to governments' request to remove content if and only if the content is in violation of YouTube's Community Guidelines, which prohibit a variety of categories of speech (including categories of speech that are protected by the First Amendment, like " insulting generalizations about people of a particular nationality".) ${ }^{56}$ Facebook provides users with a list of rights and responsibilities and indicates that it has the discretion to remove content that is in violation of these rights and responsibilities. ${ }^{57}$ Yet, Facebook has been relatively opaque in its determinations of what content to remove and does not publish a transparency report similar to that made available by Google and Google/YouTube. ${ }^{58}$

By comparison, Twitter has been both transparent and clear regarding the policies it has adopted governing content removal. In January 2012, Twitter announced its adoption of a relatively speech-protective policy by which it will censor speech within the country requesting censorship upon receipt of a valid order from the country mandating censorship. Under the policy, Twitter will provide notice to affected parties (both content providers and would-be recipients of such content) of the censorship (unless it is prohibited from doing so by law). Twitter sets forth its content removal policy as follows:

${ }^{55}$ See for example Google's Answer to the Frequently Asked Question: “ Q. Why haven't you complied with all of the content removal requests? A. There are many reasons we may not have removed content in response to a request. Some requests may not be specific enough for us to know what the government wanted us to remove (for example, no URL is listed in the request), and others involve allegations of defamation through informal letters from government agencies, rather than court orders. We generally rely on courts to decide if a statement is defamatory according to local law."

${ }^{56}$ See http://www.youtube.com/t/community_guidelines

${ }^{57}$ See https://www.facebook.com/legal/terms (providing, inter alia: "You will not bully, intimidate, or harass any user. ... You will not post content that: is hate speech, threatening, or pornographic; incites violence; or contains nudity or graphic or gratuitous violence.......You will not use Facebook to do anything unlawful, misleading, malicious, or discriminatory... You will not post content or take any action on Facebook that infringes or violates someone else's rights or otherwise violates the law....We can remove any content or information you post on Facebook if we believe that it violates this Statement or our policies.")

${ }^{58}$ See, e.g., http://lawdigitalcommons.bc.edu/cgi/viewcontent.cgi?article=1667\&context=iclr 
Many countries. . . have laws that may apply to Tweets and/or Twitter account content. [I]f we receive a valid and properly scoped request from an authorized entity, it may be necessary to reactively withhold access to certain content in a particular country from time to time.

... Upon receipt of requests to withhold content, we will promptly notify affected users unless we believe we are legally prohibited from doing so (for example, if we receive an order under seal). We also clearly indicate within the product when content has been withheld. And, we have expanded our partnership with Chilling Effects to publish ... requests to withhold content -- unless, similar to our practice of notifying users, we are legally prohibited from doing so.

Withheld Tweets:

If you see a grayed-out Tweet in your timeline . . . or on another user's account ..., it means that access to that Tweet has been withheld in your country.

Withheld accounts:

Similarly, if you see a grayed-out user in your timeline . . or elsewhere on Twitter . . , access to that particular account has been withheld in your country.

... Upon receipt of a request to withhold content, Twitter will attempt to notify affected users of the request via the email address we have on file, identifying the specific content withheld and the origin of the request, in addition to marking withheld Tweets and/or accounts with a visual indicator.

Twitter's content removal policy has many virtues. It is speech-protective in that Twitter will only withhold access for individuals within the country making that request, and it will provide notice both to the Twitter account holder and the would-be recipients of the content that the content has been withheld and the origin of the request for withholding the content. The policy therefore complies with the fourth and fifth proposed principles of digital due process, requiring the surgical implementation of blocking orders by the ICT company only within the country mandating such blocking; and the implementation of such blocking order by the ICT company in a manner that is open and transparent. However, the provision of the policy in which Twitter responds to "valid and properly scoped request from an authorized entity" leaves some room for interpretation. Depending on how Twitter interprets its requirement of a "properly scoped request," this requirement may be consistent with the first and third proposed principle of digital due process, requiring that countries articulate narrow, specific descriptions of what speech is illegal, and requiring a narrowly tailored, reasoned final judicial decision adjudicating the subject speech as illegal. Further, Twitter's content removal policy is deficient in that it merely requires a valid and properly scoped request from an authorized entity. It apparently does not require a fair, independent, and impartial judicial determination of whether the content is illegal within the country requesting that the content be withheld. Indeed, as discussed below, in its first action to withhold content 
under this policy, Twitter agreed to withhold content upon request from a non-judicial authority in Germany, as discussed below. This aspect of Twitter's policy does not comport with the second proposed principle of digital due process - ensuring that affected parties the have the opportunity to be heard in a fair, independent, and impartial judicial proceeding before a censorship decision is ordered - and is insufficiently protective of free speech, as discussed in greater detail below.

Case Studies and Recommendations For Implementation of Principles of Digital Due $\underline{\text { Process }}$

Having articulated a set of proposed principles of digital due process that ICT companies should adhere to in responding to censorship requests from governments around the world, I now examine how the implementation of these principles would have proceeded in the context of several recent cases involving restrictions on Internet speech.

\section{Case Study 1: Yildirim v. Turkey}

In Yildirim v. Turkey, Ahmet Yildirim, a national of Turkey and doctoral student, sued the Republic of Turkey for violating his free speech rights under Article 10 and his fair trial rights under Article 6 of European Convention. The difficulties arose for Yildirim in June 2009 when another website - with whom Yildirim had no connection posted content via Google Sites (a website creation platform) that allegedly insulted the memory of Mustafa Kemal Atatürk (founder of the Republic of Turkey), which constitutes a crime in Turkey. In response, the Denizli Criminal Court of the First Instance, pursuant to its law regulating Internet publications, ordered the blocking of the offending website, as a preventive measure in the context of criminal proceedings against the site's owner. The Court then sent its order requiring the blocking of the offending website to the Telecommunications and Information Technology Directorate (the "TIB") for execution. The TIB, upon receiving this narrowly targeted blocking order, complained that it did not have the means of only blocking the offending site, and instead requested that the Court modify its mandate to order the blocking of all access to Google Sites in its entirety. The Criminal Court complied, modifying its order to require the blocking of Google Sites in its entirely. The TIB then implemented this order and rendered all Google Sites content inaccessible within the country. At no time in this process did the Court or the TIB notify Google or request that Google Sites render the offending site inaccessible within Turkey. Once the TIB rendered the entire Google Sites platform and all of its content inaccessible, Yildirim - who used Google Sites as a platform to publish his academic work - was unable to access his content, including his academic articles and commentary, on his Google Sites website (available at http://sites.google.com/a/ahmetyildirim.com.tr/academic/). Yildirim applied to have the court's blocking order modified and narrowed, in favor of a method of implementation that would make only the offending website inaccessible, such as by blocking the offending site's URL. The Court dismissed Yildirim's application for a modified order, explaining that the TIB had insisted that the only means of blocking access to the offending website was to block access to the entirety of Google Sites. Three years later, after the criminal case against the owner of the offending website was dropped, the entirety of Google Sites remained blocked within Turkey and Yildirim's Google Sites website remained inaccessible within Turkey. Seeking redress, Yildirim brought an 
action against the Republic of Turkey, alleging violations, inter alia, of Article 10 and Article 6 of the European Convention.

How might this situation have been resolved in a less speech-unfriendly manner? Assuming that countries have the right to block within their country - or have blocked within their country -- web content that is illegal within their country, first, courts should craft blocking orders in as narrow and specific a manner as possible, and each global Internet platform should implement such judicial orders in as narrow and specific a manner as possible. In the Yildirim case, the Turkish criminal court - after determining that the content on the offending site violated its law prohibiting clear, precise, and narrowly drawn categories of content, and after giving the owner of the offending site notice of the charge and an opportunity to be heard by the court -- should have ordered the TIB to block access within Turkey to the offending site - and only the offending site. If the TIB was unable surgically to block access only to the offending site (as the TIB claimed was in fact the case), the TIB or the court could have requested that Google block access only to the offending website and only within Turkey. ${ }^{59}$

Once presented with a request from the Turkish criminal court or the TIB in furtherance of the court's order, Google could have taken steps to ensure that the first four digital due process requirements were met: first, that the applicable country's law articulates a narrow, specific description of what speech is illegal; second, that affected

\footnotetext{
${ }^{59}$ In the past, the Turkish government has expressed dissatisfaction with country-specific blocking, claiming that Internet content illegal within Turkey - like the content at issue in the offending website that allegedly insulted the memory of Ataturk -- should be rendered inaccessible by Google for all Internet users, including those outside of Turkey. For example, in June 2008, after Google agreed to block access within Turkey to a series of videos on YouTube that a Turkish court held were violative of Turkish law, see http://www.bbc.co.uk/news/10480877, the Turkish government was apparently unsatisfied and demanded that Google implement worldwide blocking of such content, claiming that a worldwide block was necessary to protect the rights and sensitivities of Turks living outside of Turkey. See Jeffrey Rosen, Google's Gatekeepers, The New York Times, November 30, 2008. When Google refused to expand the scope of the geographic scope of the block to all countries, the Turkish government decided to block access to all of YouTube, which it proceeded to do for the next two and a half years, until the offending videos were removed from YouTube (by a party other than YouTube itself). See http://www.bbc.co.uk/news/technology-11659816. Indeed, Turkey blocked not only YouTube but also a host of other Google services, because it was apparently unclear which of Google's designated IP addresses it was using for YouTube services and which it was using for other services. See http://www.bbc.co.uk/news/10480877. In such a case, it is unreasonable for Turkey to seek to export its idiosyncratic, country-specific laws regarding illegal content, and it is further unreasonable to block access to the entire video-sharing platform of YouTube - and other unrelated Google services -- because of a small handful of offending websites on YouTube that YouTube had already agreed to block for residents of Turkey.
} 
Internet users received meaningful notice of categories of illegal speech and had opportunity to be heard by a court before their right to freedom of speech/information is abridged; third, that decisions to block content were made in an impartial, independent judicial proceeding; and fourth, that the court's decision was narrowly tailored to avoid collateral censorship/overbreadth and specified precisely which Internet speech is illegal. Once it was satisfied that the country and its courts met the requirements of digital due process, Google should then implement its technology in general and the blocking order in particular in a manner that comports with digital due process by first, implementing the court's decision in a manner that is narrow, open and transparent. The blocking order should be narrowly implementing to block access only to the content judicially determined to be illegal and only within the country making that determination. The blocking order should be implemented in an open and transparent manner, so as give meaningful notice to those seeking access to the blocked site that Google blocked the site in accordance with a valid court order.

\section{Case Study 2: Twitter and Blocking of Neo-Nazi Tweets}

In October 2012, Twitter received from German police a request to close the account of the neo-Nazi organization of Besseres Hannover. The German police informed Twitter that Besseres Hannover "is disbanded, its assets are seized and all its accounts in social networks have to be closed immediately." The police asked that Twitter block Besseres Hannover's account and prevent it from opening alternate accounts. ${ }^{60}$ In the first instance of its implementation of its new censorship policy, Twitter responding by blocking the tweets of the organization within Germany, but declining to close the organization's account. Twitter also provided notice to German users that this organization's tweets were blocked within Germany, and provided access to the German authorities' documents requesting the block. Under the policy, Besseres Hannover's tweets will appear to German users as greyed-out boxes with the words "@Username withheld" and "This account has been withheld in: Germany." ${ }^{61}$ Twitter

\footnotetext{
${ }^{60}$ See https://www.chillingeffects.org/notice.cgi?sID=625342 (providing letter from the Head of the Police Administration Department, Hannover, Germany, to Twitter, which indicates: "the Ministry of the Interior of the State of Lower-Saxony in Germany has banned the organisation "Besseres Hannover". It is disbanded, its assets are seized and all its accounts in social networks have to be closed immediately. The Public Prosecutor (State Attorney's Office) has launched an investigation on suspicion of forming a criminal association. It is the task of the Polizeidirektion Hannover (Hannover Police) to enforce the ban. The organisation "Besseres Hannover" uses the Twitter account besseres-hannover@hannoverticker https://twitter.com/hannoverticker. I ask you to close this account immediately and not to open any substitute accounts for the organisation "Besseres Hannover".)

61 http://www.slate.com/blogs/future_tense/2012/10/18/twitter_censors_neo_nazi_group_besseres_h annover_is_first_user_blocked_under.html
} 
has also received requests from countries to make available the identities of individuals who post illegal content. ${ }^{62}$

How might this situation have been resolved in a less speech-unfriendly manner? Although Twitter's implementation of its "country-withheld content" policy is relatively speech-protective, the policy suffers in that it does not require that the content's illegality be determined in the context of a fair, impartial, and independent judicial determination. Twitter should only block access to this organization's tweets when and if it receives an order resulting from an impartial, independent judicial proceeding determining that this speech was illegal.

Case Study 3: Turkey's Demand that YouTube Block Access Throughout the World to Video Content that Violated Turkish Law

The Republic of Turkey has had a tumultuous relationship with Google/YouTube. In March 2007, a Turkish judge ordered the nation's telecommunications providers to block access to all of YouTube in response to videos that allegedly insulted the founder of the Republic of Turkey Mustafa Kemal Ataturk, which is a crime in Turkey. The video that initially sparked the controversy was a parody news broadcast that declared, "Today's news: Kamal Ataturk was gay!'” posted by Greek soccer fans to insult their Turkish rivals. The ban on YouTube was ordered and implemented by Turkish officials without consulting with Google/YouTube and without asking the company to surgically block access to only the offending video. The offending video was eventually taken down, apparently by the individuals who initially posted it, but even after it was taken down, Turkish prosecutors found dozens of other YouTube videos that they claimed insulted either Ataturk or "Turkishness," in order to justify the continued blocking of YouTube in its entirety.

Upon learning that access to all of YouTube was being blocked in Turkey, Google executives worked to develop a solution that would placate Turkish officials. The executives set about attempting to determine which videos were clearly in violation of Turkish law prohibiting insults to Ataturk or Turkishness, and then blocking access to those videos within Turkey. Google's plan seemed to be satisfactory to Turkish authorities for a period of time, but then in June 2007, a Turkish prosecutor demanded that Google block access to the offending videos not just in Turkey but throughout the world, asserting the need to protect the rights and sensitivities of Turks living outside the country. Google refused to implement this extraterritorial blocking mandate, and in response, the Turkish government once again blocked access to YouTube in its entirety.

\footnotetext{
${ }^{62}$ In January 2013, a French court ordered Twitter to identify people who had posted anti-Semitic and racist entries on the social network. See http://www.nytimes.com/2013/01/25/technology/twitter-ordered-to-help-revealsources-of-anti-semitic-posts.html?_r=0
} 
How might this situation have been resolved in a less speech-unfriendly manner? First, Google should determine whether Turkey has articulated its laws prohibiting attacks on Ataturk and Turkishness in a narrow and precise manner, so as to provide individuals within Turkey with adequate notice as to what content is prohibited. Second, Turkish courts should provide the owners of offending sites with notice of the charge and an opportunity to be heard by the court determining whether their content violated Turkish law. Third, if warranted, the Turkish court should craft any blocking orders in as narrow and specific a manner as possible with the least impact on freedom of expression. Google/YouTube should not block access to content on its own, without a valid court order identifying specifically which content is to be blocked. Fourth, Google should implement any valid court blocking orders only with respect to individuals within Turkey, rendering such content inaccessible only for individuals within Turkey. The Turkish government's request to block access to such sites throughout the world - in order to protect the rights and sensitivities of Turks living outside the country -- oversteps that sovereign's authority and jurisdiction. Fifth, Google should implement any valid court blocking order in a manner that is open and transparent and provides notice to affected individuals that the requested content has been blocked because of a court order, so that those individuals can hold their government properly accountable for its speechrestrictive decisions.

\section{Conclusion}

Global ICT companies like Google, Facebook, Twitter, and Yahoo enjoy great power to control what expression is facilitated and what expression is censored in the global marketplace of ideas. And, in the words of Voltaire (and Spiderman), with great power comes great responsibility. ICT companies should wield their great power responsibly, which means adhering to the principles of digital due process that are implicit in the foundational instruments of the International Covenant of Civil and Political Rights, the European Convention on Human Rights, and the United States Constitution. 